\title{
Changes of Root-Zone Soil Environment in Flooded Paddy Field under Controlled Drainage Conditions
}

\author{
Menghua Xiao ${ }^{1 *}$, Zimei Miao², Yuanyuan $\mathrm{Li}^{3}$ \\ 'Zhejiang Institute of Hydraulics and Estuary, 310020, P.R. China \\ ${ }^{2}$ Research Center of Fluid Machinery Engineering and Technology, Jiangsu University, 212013, P.R. China \\ ${ }^{3}$ North China University of Water Resources and Electric Power, \\ School of Water Conservancy, 450045, P.R. China
}

Received: 7 May 2016

Accepted: 3 November 2016

\begin{abstract}
At present, farmland-controlled drainage is of great significance for water-logging control, water conservation, and emissions reduction. This paper focused on the water level of farmland to study the changes of root-zone soil environment in a flooded paddy field. Such technical indexes included the soil nutrient index of rapid available phosphorus (RAP) and rapid available nitrogen (RAN) in the $0-10 \mathrm{~cm}$ and 10-20 cm soil layers, the soil aeration condition index Eh value in the $15 \mathrm{~cm}$ soil layer, and soil temperature (ST), respectively, in the $5 \mathrm{~cm}$ and $20 \mathrm{~cm}$ soil layers. Additionally, this paper presented an analysis on the impact of water flooding in a paddy field on the soil's microenvironment using the principal component factor method. Influence analysis results showed that different water level controls between CK (shallow and wetting irrigation) and F1 and F2 (controlled drainage) had a significant effect on the changes of RAN content in the $0-10 \mathrm{~cm}$ layer, Eh value in the $15 \mathrm{~cm}$ layer, and ST value in the $5 \mathrm{~cm}$ layer, but different leakage intensities had no significant effect on the change of RAN, RAP, Eh, and ST. The results showed that water-flooding can improve the RAP content, reduce the RAN content of every soil layer, deteriorate the soil aeration status, and increase the soil temperature; additionally, the water-flooding had an adverse impact on the soil's RAP, RAN, Eh, and ST at the tillering and milking stages. Water-flooding also had an adverse impact on the soil's RAN and Eh at the jointing-booting and heading-flowering stages.
\end{abstract}

Keywords: water flooding, soil nutrient, soil aeration, soil temperature, factor analysis

\section{Introduction}

To ease the contradictions between water supply and demand in a stable rice planting area, water-saving irrigation techniques of rice have been widely researched [1-3]. China is the largest producer and consumer of synthetic fertilizers in the world. Its total fertilizer consumption reached 46.3 billion $\mathrm{kg}$ in 2004 - more than one-third of the world's consumption [4]. Its partial factor productivity from applied nitrogen $(\mathrm{N})$ decreased from 55.0 to $20.0 \mathrm{~kg} \mathrm{ha}^{-1}$ from 1997 to 2005 [5]. A large amount

*e-mail: menghuaxiao@aliyun.com 
of $\mathrm{N}$ element entered into the ambient water bodies, and the resulting atmosphere in water eutrophication through various means [6-8]. However, rice crops are swampy, with a certain degree of submergence tolerance, thus it is an efficient way to build a certain depth of stagnant water layer through the paddy field in the main flood season, which can enhance rainwater use efficiency and save irrigation water, but also store some of the flood water, relieving pressure on regional flooding. Therefore, the paddy field controlled drainage technology has attracted attention.

Controlled drainage research began in the late 1970s, especially in Europe and America [9-10]. Domestic controlled drainage research began in the late 1990s. Controlled drainage can play the roles as follows. Firstly, it could reduce the frequency of irrigation to reduce demand pressures on water resources [11]. Secondly, controlled drainage could reduce the concentration of nitrogen $(\mathrm{N})$ and phosphorus (P) in the drainage channel, which mainly relies on crop uptake [12], nitrification-denitrification [13], and sediment deposition [14]. Lastly, it is an effective measure to improve the utilization of rainwater resources and avoid water-logging and salinization by controlling the retention time of storm water in fields and drains [1516].

Paddy field controlled drainage makes water conditions different from traditional ones. As the water condition changes, the soil microenvironment of the paddy field is bound to change, which may directly and indirectly impact soil fertility factors, including moisture, nutrients, aeration, temperature, etc., which then further impact the growth and development of the paddy rice. Among soil fertility factors, moisture plays a dominant role [17]. Control on the water level of farmland causes the soil moisture content to change, which then further impacts other soil fertility factors. Firstly, soil moisture and air coexist in soil pores, with both of them growing and mutually declining each other where the change in soil moisture content is the main reason to cause changes of soil air; secondly, the relationship of the proportion between soil moisture and aeration dominates the thermal property of soil and affects soil temperature; lastly, the crops absorb the nutrients only through water. The nutrients can only play their roles in conjunction with appropriate water. Generally, the regulation of soil water, fertilizer, aeration, and heat condition focuses on the regulation on soil moisture, where the purpose of regulating the temperature and air and improving fertilizer through water and making comprehensive regulation is achieved through the regulation on soil moisture.

At present, most of the existing reports focus on $\mathrm{N}$ and $\mathrm{P}$ losses and paddy water quality purification [1819], and the research on soil fertility usually focuses on a single fertility, with less consideration on the overall change law of soil water, fertilizer, and heat under the influence of external conditions [2-21]. By taking the water level of farmland as the technical index, our paper studies the change law of the root-zone soil fertility in the flooded paddy field under controlled drainage conditions, discloses the impact of the water level change on the microenvironment of the root-zone soil, and provides a reliable basis for exploring the changes of soil microenvironment and investigating the impact of the controlled-drainage on soil fertility. Additionally, the paper is vitally significant for selecting the controlleddrainage standard for the different growth stages of the preference paddy rice. Moreover, the principal component analysis approach among the multiple objective decision analysis approach was adopted in this paper to analyze the four indexes of RAP and RAN in 10-20 cm soil layers, Eh in the $15 \mathrm{~cm}$ soil layer, and ST in the $20 \mathrm{~cm}$ soil layers. It reveals the degree of water-flooding on the soil fertility factor, which has important significance for evaluating controlled drainage schemes.

\section{Materials and Methods}

\section{Experimental Area and the Soil}

The study was conducted in 2014 and 2015 at the saving water and agro-ecological experimental plot on Jiangning Campus of Hohai University, Jiangsu Province, China. The region has a subtropical humid monsoon climate zone, with an average annual evaporation of $900 \mathrm{~mm}$, yearly average temperature of $15.4^{\circ} \mathrm{C}$, and maximum and minimum air temperatures of $43.0^{\circ} \mathrm{C}$ and $-14.0^{\circ} \mathrm{C}$, respectively. Mean annual rainfall is $1,041 \mathrm{~mm}$, of which more than $60 \%$ of precipitation happens in the rainy season (namely from May to September), and there are 220 frost-free days per year. The soil in the area is a typical permeable paddy soil formed on the loess deposits, with loamy clay. The area adopts a five-year rice-wheat rotation system. There are 32 fixed lysimeter plots ( 28 with closed bottom and 4 without) with the specifications of $2.5 \mathrm{~m}$ length, $2 \mathrm{~m}$ width, and $2 \mathrm{~m}$ depth. The lysimeter layout is divided into two groups, with each group containing 16 plots. The underground corridors and underground equipment rooms are built between the two groups and the mobile canopy is equipped on the ground. The irrigation system is an automatic irrigation system controlled by the host-electromagnetic valve (Fig. 1). The topsoil $(0-30 \mathrm{~cm})$ with $\mathrm{pH}$ value of 6.97 in lysimeter contained $2.40 \%$ soil organic matter, $0.9048 \mathrm{gkg}^{-1}$ of total nitrogen, $27.65 \mathrm{mgkg}^{-1}$ of available nitrogen, $0.32 \mathrm{gkg}^{-1}$ of total phosphorus, and $12.5 \mathrm{mgkg}^{-1}$ of available phosphorus.

\section{Experimental Design}

The paddy rice experiences six stages in its whole cultivation period after the paddy rice seedlings are transplanted to the fields, i.e., the re-greening, tillering, jointing-booting, heading-flowering, and the milking and ripening stages. According to the characteristics of the paddy rice growth stage, tillering, jointing-booting, heading-flowering, and milking stages were chosen to conduct the experiment under flooded conditions at 


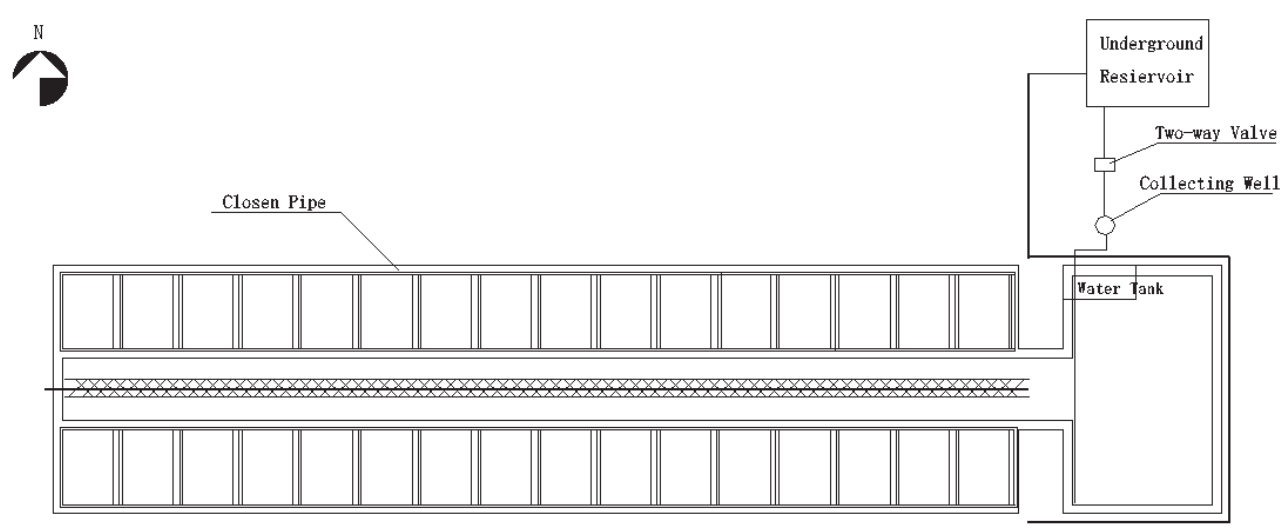

Fig.1. Layout of the study area and experimental management.

different leakage rates. Eight treatments were set up in the lysimeter plots with closed bottoms, one treatment was set up in the lysimeter without bottom and each treatment was repeated four times. Ten days of each stage were conducted with water level control to satisfy the leakage set via irrigation and drainage, while the other days of stage were conducted with water management complying with the requirement of shallow and wetting irrigation. Water control programs in 2014 and 2015 are shown in Table 1. Three different inorganic fertilizers were supplied at the time of seeding and during cultivation. Only the basal fertilizers were incorporated into the surface soil and the other fertilizations were applied on the surface. The basal fertilizer was a compound fertilizer (N: $\mathrm{P}_{2} \mathrm{O}_{5}: \mathrm{K}_{2} \mathrm{O}$ as 15:15:15\%), 1,200 $\mathrm{kg} \mathrm{ha}^{-1}$, applied on 13 June 2014 and 30 June 2015, respectively; the tillering fertilizer applied was the urea (nitrogen content 46.4\%), $647 \mathrm{~kg} \mathrm{ha}^{-1}$ on 28 June 2014 and 6 July 2015, respectively, and the panicle fertilizer applied also was the urea (nitrogen content 46.4\%), $647 \mathrm{~kg} \mathrm{ha}^{-1}$ on 9 August 2014 and 6 August 2015, respectively, where the weeding was controlled manually and the pesticide was applied occasionally.

\section{Sample Collection and Analysis}

Water level regulation was conducted for 10 days at each paddy rice growth stage in a paddy field. Soil samples were selected respectively in the $0-10 \mathrm{~cm}$ and $10-20 \mathrm{~cm}$ soil layer on the day before being flooded $($ DAT $=-1)$, on days $1($ DAT $=1), 5($ DAT $=5)$, and 10 $(\mathrm{DAT}=10)$ during the flooded period, and on the second day after the end of flooding (DAT $=12$ ). We used a fivepoint method to select soil samples at each lysimeter plot. When selecting the soil sample, we used a tube-type earthboring auger to drill holes and then inserted it to extract soil samples, which were dried naturally, ground, sifted, blended, and stored in wide-mouthed bottles with clear markings. Afterward, RAN was measured by using the base diffusion method and the RAP was measured using the $\mathrm{NH}_{4} \mathrm{~F}-\mathrm{HCl}$ method. The Eh of the soil at its layer of $15 \mathrm{~cm}$ was measured by using the PH/MV meter of PHB06 at 09:00 on the day before being flooded and days 1 $(\mathrm{DAT}=-1), 2(\mathrm{DAT}=2), 4(\mathrm{DAT}=4), 6(\mathrm{DAT}=6), 8(\mathrm{DAT}$ $=8)$, and $10(\mathrm{DAT}=10)$ during the flooded period, and the second $(\mathrm{DAT}=12)$ and fourth days $(\mathrm{DAT}=14)$ after the end of flooding. The ST was automatically collected every

Table 1. Water control programs in 2014 and 2015. Positive value was flooding depth while negative value was the length from field surface to underground water level, and value in parentheses represented the daily leakage intensity.

\begin{tabular}{|c|c|c|c|c|c|c|}
\hline Treatment & Tillering stage & $\begin{array}{c}\text { Jointing-booting } \\
\text { stage }\end{array}$ & $\begin{array}{l}\text { Heading- } \\
\text { flowering stage }\end{array}$ & Milky stage & \multicolumn{2}{|c|}{ Flooding time } \\
\hline $\mathrm{F} 1$ & $120 \mathrm{~mm}(2 \mathrm{~mm} / \mathrm{d})$ & $-300 \mathrm{~mm} \sim 30 \mathrm{~mm}$ & $-300 \mathrm{~mm} \sim 30 \mathrm{~mm}$ & $-300 \mathrm{~mm} \sim 30 \mathrm{~mm}$ & \multirow{2}{*}{$\begin{array}{c}\text { Jul.6-Jul. } \\
15.2014\end{array}$} & \multirow{2}{*}{$\begin{array}{c}\text { Jul.19-Jul. } \\
28.2015\end{array}$} \\
\hline $\mathrm{F} 2$ & $120 \mathrm{~mm}(4 \mathrm{~mm} / \mathrm{d})$ & $-300 \mathrm{~mm} \sim 30 \mathrm{~mm}$ & $-300 \mathrm{~mm} \sim 30 \mathrm{~mm}$ & $-300 \mathrm{~mm} \sim 30 \mathrm{~mm}$ & & \\
\hline F3 & $-200 \mathrm{~mm} \sim 20 \mathrm{~mm}$ & $250 \mathrm{~mm}(2 \mathrm{~mm} / \mathrm{d})$ & $-300 \mathrm{~mm} \sim 30 \mathrm{~mm}$ & $-300 \mathrm{~mm} \sim 30 \mathrm{~mm}$ & \multirow{2}{*}{$\begin{array}{c}\text { Jul.29-Aug. } \\
7.2014\end{array}$} & \multirow{2}{*}{$\begin{array}{c}\text { Aug.14-Aug. } \\
23.2015\end{array}$} \\
\hline $\mathrm{F} 4$ & $-200 \mathrm{~mm} \sim 20 \mathrm{~mm}$ & $250 \mathrm{~mm}(4 \mathrm{~mm} / \mathrm{d})$ & $-300 \mathrm{~mm} \sim 30 \mathrm{~mm}$ & $-300 \mathrm{~mm} \sim 30 \mathrm{~mm}$ & & \\
\hline F5 & $-200 \mathrm{~mm} \sim 20 \mathrm{~mm}$ & $-300 \mathrm{~mm} \sim 30 \mathrm{~mm}$ & $250 \mathrm{~mm}(2 \mathrm{~mm} / \mathrm{d})$ & $-300 \mathrm{~mm} \sim 30 \mathrm{~mm}$ & \multirow{2}{*}{$\begin{array}{c}\text { Aug.24-Sep. } \\
2.2014\end{array}$} & \multirow{2}{*}{$\begin{array}{l}\text { Aug.30-Sep. } \\
\quad 8.2015\end{array}$} \\
\hline F6 & $-200 \mathrm{~mm} \sim 20 \mathrm{~mm}$ & $-300 \mathrm{~mm} \sim 30 \mathrm{~mm}$ & $250 \mathrm{~mm}(4 \mathrm{~mm} / \mathrm{d})$ & $-300 \mathrm{~mm} \sim 30 \mathrm{~mm}$ & & \\
\hline F7 & $-200 \mathrm{~mm} \sim 20 \mathrm{~mm}$ & $-300 \mathrm{~mm} \sim 30 \mathrm{~mm}$ & $-300 \mathrm{~mm} \sim 30 \mathrm{~mm}$ & $250 \mathrm{~mm}(2 \mathrm{~mm} / \mathrm{d})$ & \multirow{2}{*}{$\begin{array}{c}\text { Sep.15-Sep } \\
24.2014\end{array}$} & \multirow{2}{*}{$\begin{array}{c}\text { Sep.12-Sep } \\
.21 .2015\end{array}$} \\
\hline F8 & $-200 \mathrm{~mm} \sim 20 \mathrm{~mm}$ & $-300 \mathrm{~mm} \sim 30 \mathrm{~mm}$ & $-300 \mathrm{~mm} \sim 30 \mathrm{~mm}$ & $250 \mathrm{~mm}(4 \mathrm{~mm} / \mathrm{d})$ & & \\
\hline CK & $-200 \mathrm{~mm} \sim 20 \mathrm{~mm}$ & $-300 \mathrm{~mm} \sim 30 \mathrm{~mm}$ & $-300 \mathrm{~mm} \sim 30 \mathrm{~mm}$ & $-300 \mathrm{~mm} \sim 30 \mathrm{~mm}$ & Jul.6-Oct.1 & Jul.19-Oct.7 \\
\hline
\end{tabular}


six minutes by the AD590 current source type temperature sensor embedded in the lysimeter; afterward, the ST in the $5 \mathrm{~cm}$ and $20 \mathrm{~cm}$ soil layers on the day before being flooded $(\mathrm{DAT}=-1)$ and days $5(\mathrm{DAT}=5)$ and $10(\mathrm{DAT}=10)$ during the flooded period, and the second day $(\mathrm{DAT}=12)$ after the end of being flooded was respectively observed at 06:00 to avoid the interference of other factors.
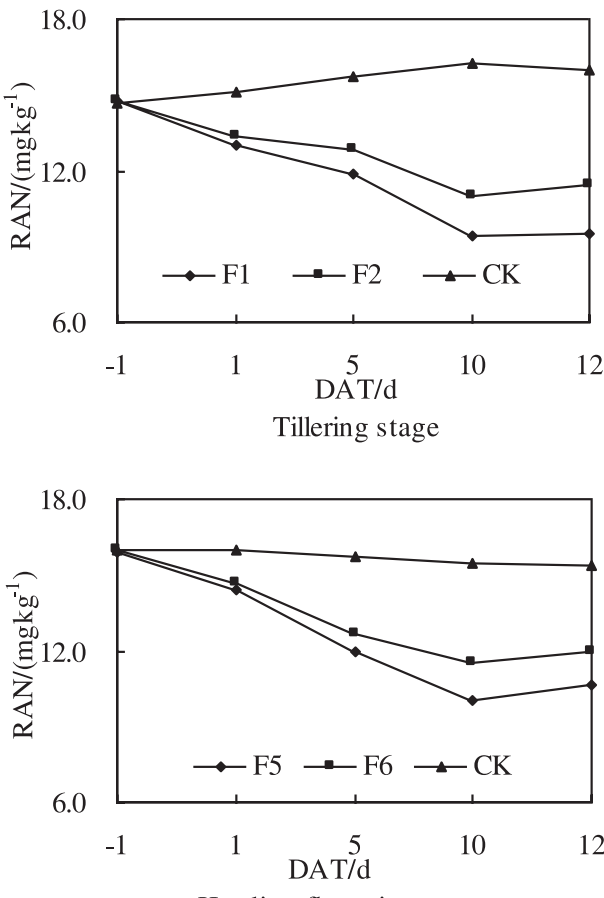

Heading-flowering stage
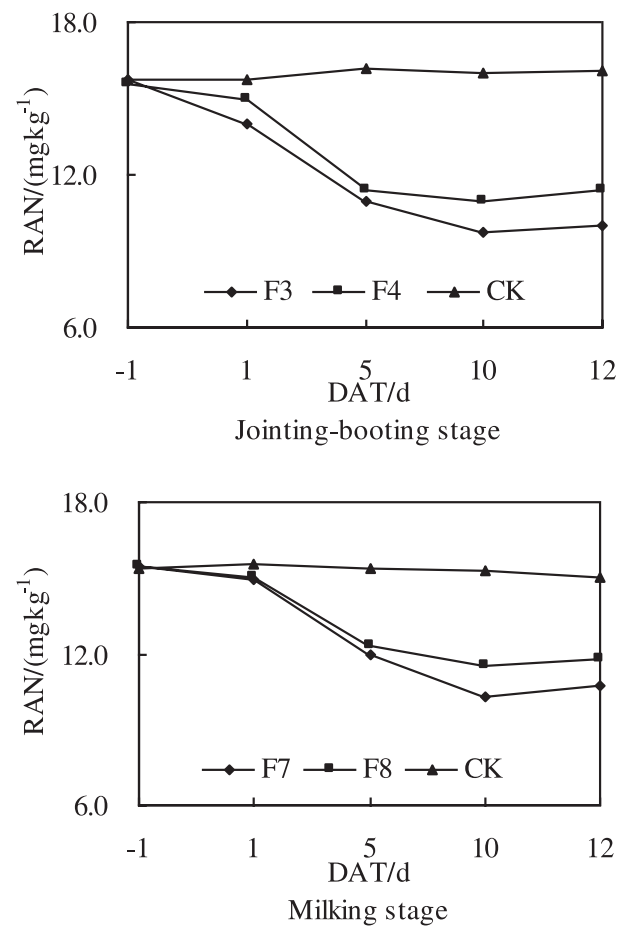

a) $0-10 \mathrm{~cm}$ layer
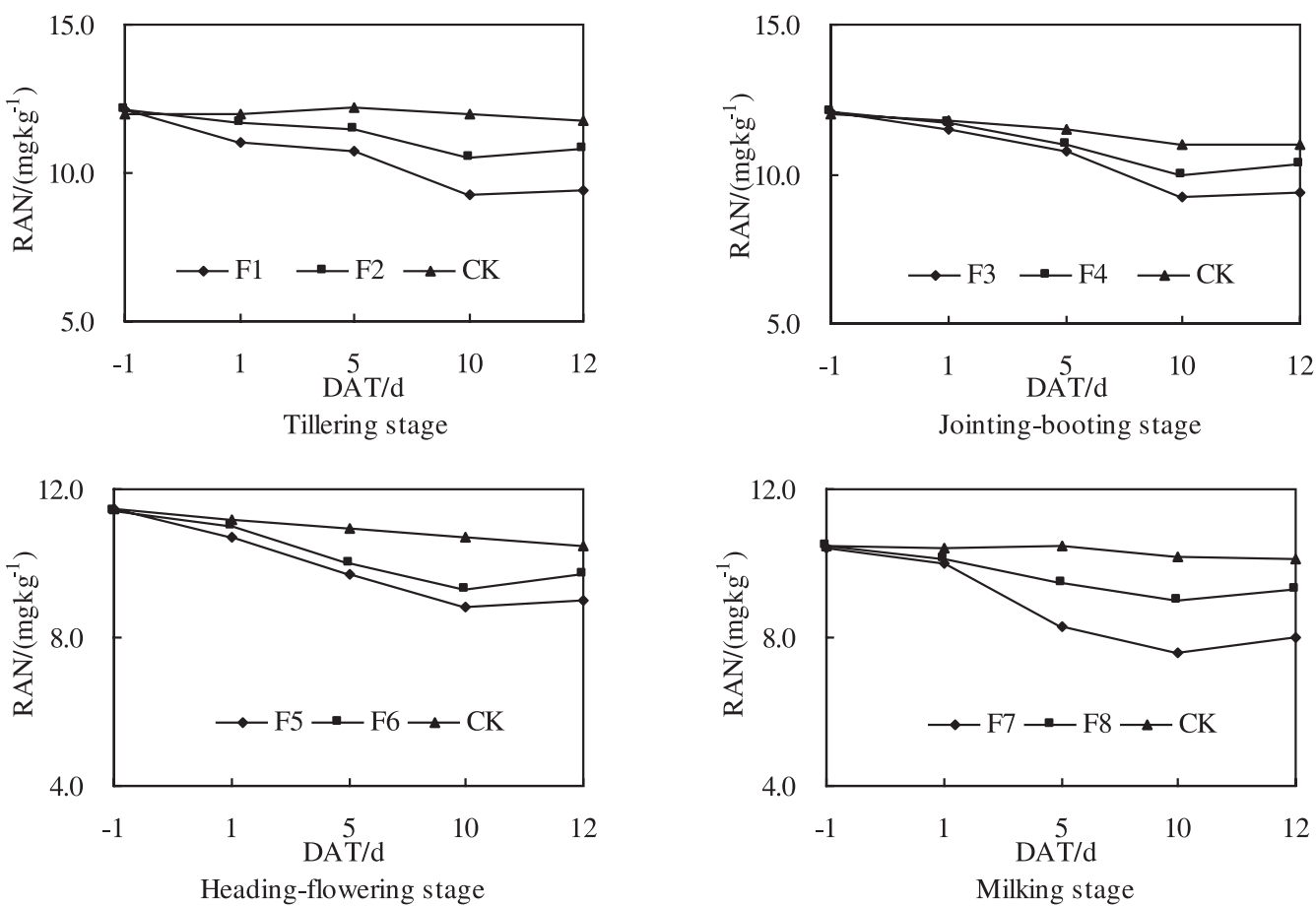

b) $10-20 \mathrm{~cm}$ layer

Fig. 2. Changes of RAN content in the a) 0-10 cm and b) 10-20 cm soil layers at each growth stage in the flooded paddy field. 
decreased along with increasing soil depth. There were little differences in the RAN content under each treatment before the water level was controlled. During the flooded period, the RAN content of the soil layers of $0-10 \mathrm{~cm}$, by contrast with the treatment of $\mathrm{CK}$ at the tillering and the jointing-booting stage, was increased along with the flood duration increase, but was reduced somewhat at the heading-flowering and the milking stage. The RAN content of flooded treatment presented a decrement tendency, and compared with the ones on the days 1 and 10 of being flooded, F1 and F2 at the tillering stage was respectively decreased by $27.7 \%$ and $17.9 \%$, F3 and F4 at the jointing-booting stage respectively decreased by $30.7 \%$ and $26.7 \%$, F5 and F6 at the heading-flowering stage respectively decreased by $30.5 \%$ and $21.8 \%$, and F7 and F8 at the milking stage respectively decreased by $30.9 \%$ and $23.3 \%$. By contrast with the CK treatment, $\mathrm{F} 1$ and F2 at the tillering stage respectively reduced $5.9 \mathrm{mgkg}^{-1}$ and $5.3 \mathrm{mgkg}^{-1}, \mathrm{~F} 3$ and F4 at the jointingbooting stage respectively reduced $5.3 \mathrm{mgkg}^{-1}$ and $5.0 \mathrm{mgkg}^{-1}, \mathrm{~F} 5$ and F6 at the heading-flowering stage respectively reduced $5.5 \mathrm{mgkg}^{-1}$ and $4.0 \mathrm{mgkg}^{-1}$, and F7 and F8 at the milking stage respectively reduced $5.0 \mathrm{mgkg}^{-1}$ and $3.8 \mathrm{mgkg}^{-1}$ on the 10th flooded day. The sharp reduction of the RAN content through the flooded treatment was mainly caused by the following factors, i.e., there was a certain leakage at the early flooded period, where the nitrate nitrogen in the surface soil moved downward along with the percolating water and accumulated at the airtight reduction layer possibly; on the other hand, as the flooded duration continued, the soil reduction potential became larger and larger, the permeability of the soil became worse, the soil reducing property was enhanced, the nitrification was inhibited, and denitrification was promoted. This was identical with the results of $\mathrm{Lu}[22]$. For the $10-20 \mathrm{~cm}$ soil layers during the flooded period, the CK treatment decreased slowly, but the flooded treatment decreased rapidly, the decrease amplitude was smaller than that of 10-20 cm. Compared with the $1^{\text {st }}$ flooded day, F1 and F2 at the tillering stage respectively decreased $15.4 \%$ and $10.3 \%, \mathrm{~F} 3$ and $\mathrm{F} 4$ at the jointing-booting stage respectively decreased $20.0 \%$ and $14.5 \%, \mathrm{~F} 5$ and $\mathrm{F} 6$ at the heading-flowering stage respectively decreased $17.8 \%$ and $15.5 \%$, and F7 and F8 at the milking stage respectively decreased $24.0 \%$ and $10.9 \%$ on the $10^{\text {th }}$ flooded day. Compared with the CK treatment, F1 and F2 at the tillering stage respectively reduced $2.7 \mathrm{mgkg}^{-1}$ and $1.5 \mathrm{mgkg}^{-1}, \mathrm{~F} 3$ and F4 at the jointing-booting stage respectively reduced $1.8 \mathrm{mgkg}^{-1}$ and $1.0 \mathrm{mgkg}^{-1}, \mathrm{~F} 5$ and $\mathrm{F} 6$ at the heading-flowering stage respectively reduced $1.9 \mathrm{mgkg}^{-1}$ and $1.4 \mathrm{mgkg}^{-1}$, and F7 and F8 at the milking stage respectively reduced $2.6 \mathrm{mgkg}^{-1}$ and $1.2 \mathrm{mgkg}^{-1}$ on the $10^{\text {th }}$ flooded day. After the flood duration, the RAN of CK at every soil layer changed little, but the RAN content of the flooded treatment increased slightly. Additionally, the RAN content of soil under the treatment of the leakage intensity of 2 and $4 \mathrm{~mm} / \mathrm{d}$ changed in the same trend: the greater the leakage, the higher the RAN content (because the increased leakage improved soil aeration conditions). After the end of controlled-drainage, the RAN content of flooded treatment rose slightly, which was related to the changes in the flooded environment of the paddy field.

\section{Changes of Rapid Available Phosphorus in Paddy Soil}

The RAP content of each layer was shown in Fig. 3, from which it can be seen that the RAP content of the soil decreased along with the increasing soil layer depth, the RAP content of each treatment under the controlleddrainage condition inordinately, and the RAP content of flooded treatment was higher than that of CK. For the 0-10 cm soil layers, the RAP content of flooded treatment was increased, which was caused by the release of the phosphorus absorbed after the $\mathrm{Fe}^{3+}$ was transformed into the $\mathrm{Fe}^{2+}$ under the anaerobic reduction conditions caused by the flooded environment on the one hand and some organic negative ions substituted for the hydrolyzation of the phosphor, iron phosphate, and aluminium absorbed partially, and the $\mathrm{H}_{2} \mathrm{~S}$ made the ferrous phosphate release the phosphoric acid on the other hand. Additionally, the increment of the phosphorus diffusion coefficient also led the RAP content to increase. As the flood period continued, the RAP content was reduced to the minimum on the fifth flooded day, which is mainly when the soil has a higher phosphorus concentration and there is a certain gap between the soil and the phosphorus concentration in water, which makes the phosphorus originally adsorbed by the soil colloidal released into the water; afterward, the RAP content rose, which was mainly caused by the $\mathrm{Fe}^{3+}$ and $\mathrm{Fe}^{2+}$ mixed hydroxide precipitating in great quantities, which has large surface area and more phosphorus adsorption areas that can enhance the soil retention capacity on phosphorus, and the soil phosphorus adsorption capacity on amorphous $\mathrm{Fe}^{3+}$ and $\mathrm{Fe}^{2+}$ mixed hydroxide was larger than their phosphorus release capacity toward the water. On the 10th flooded day and compared with $\mathrm{CK}, \mathrm{F} 1$ and F2 at the tillering stage respectively increased by $2.0 \mathrm{mgkg}^{-1}$ and $1.7 \mathrm{mgkg}^{-1}$, F3 and F4 at the jointing-booting stage respectively increased by $0.8 \mathrm{mgkg}^{-1}$ and $0.4 \mathrm{mgkg}^{-1}, \mathrm{~F} 5$ and F6 at the heading-flowering stage respectively increased by $0.8 \mathrm{mgkg}^{-1}$ and $0.5 \mathrm{mgkg}^{-1}$, and F7 and F8 at the milking stage respectively increased by $0.7 \mathrm{mgkg}^{-1}$ and $0.3 \mathrm{mgkg}^{-1}$. After finishing the controlled-drainage, the RAP content was reduced. Different from that of the soil layers of $0-10 \mathrm{~cm}$, for the $0-20 \mathrm{~cm}$ soil layers, the peak value of the RAP content appeared on the first flooded day at the tillering and the milking stages and on the 10th flooded day at the jointing-booting and the headingflowering stage. On the 10th flooded day and compared with $\mathrm{CK}, \mathrm{F} 1$ and $\mathrm{F} 2$ at the tillering stage respectively increased by $0.3 \mathrm{mgkg}^{-1}$ and $0.1 \mathrm{mgkg}^{-1}, \mathrm{~F} 3$ and F4 at the jointing-booting stage increased by $0.5 \mathrm{mgkg}^{-1}$ and $0.1 \mathrm{mgkg}^{-1}, \mathrm{~F} 5$ and $\mathrm{F} 6$ at the heading-flowering stage increased by $0.4 \mathrm{mgkg}^{-1}$ and $0.3 \mathrm{mgkg}^{-1}$, and F7 and F8 at 

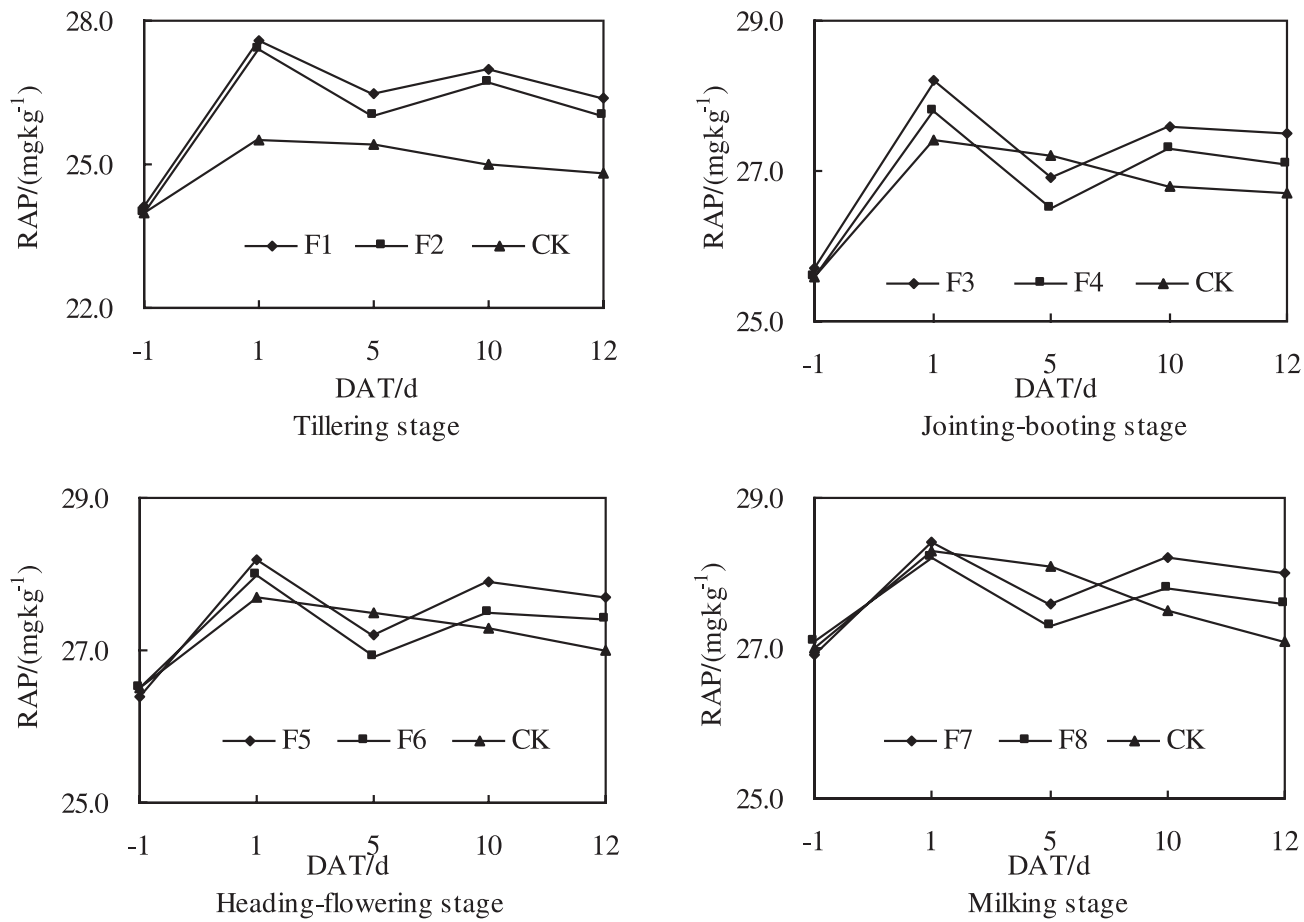

a) 0-10 cm layer
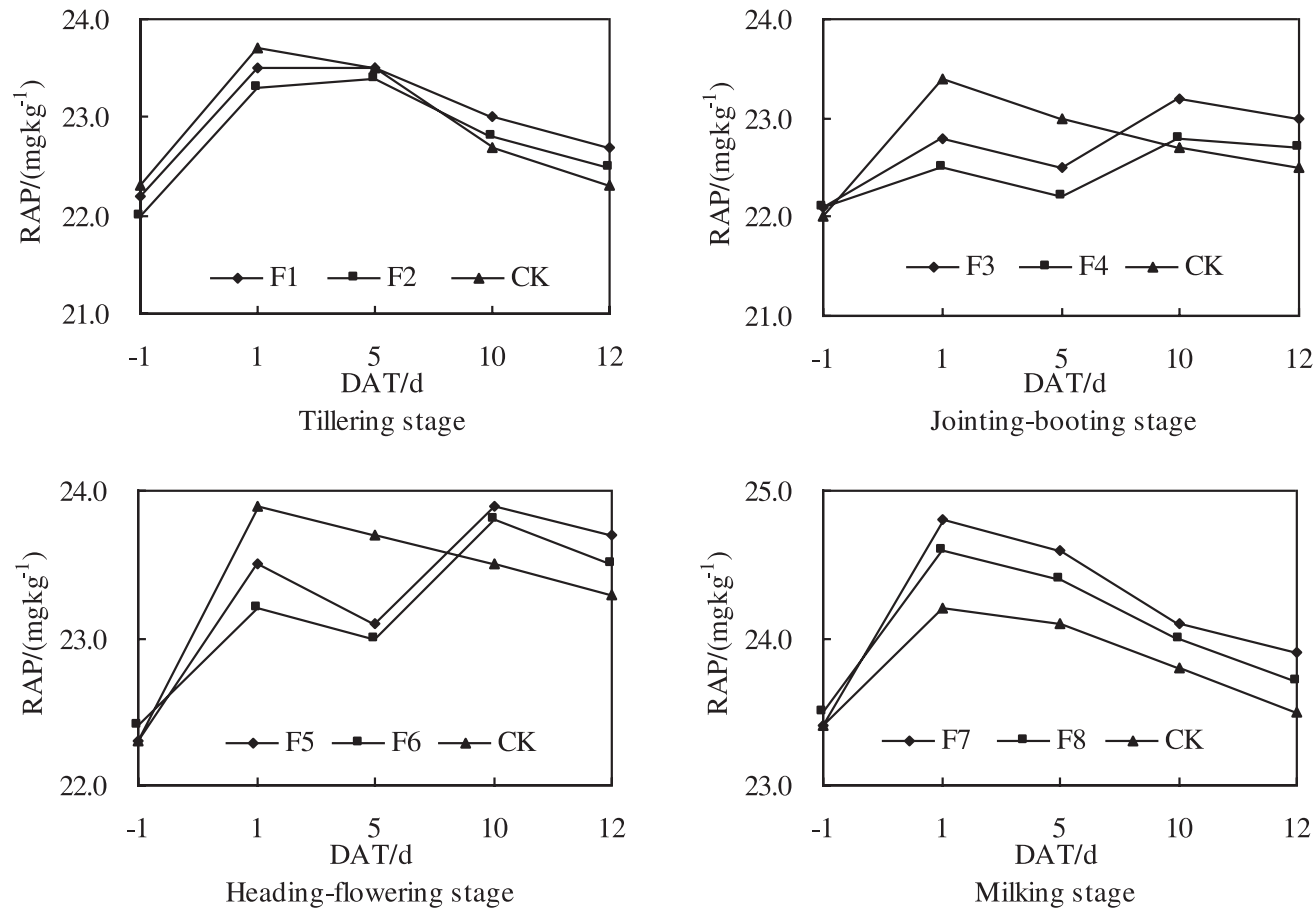

b) $10-20 \mathrm{~cm}$ layer

Fig. 3. Changes of RAP content in the a) $0-10 \mathrm{~cm}$ and b) $10-20 \mathrm{~cm}$ soil layers at each growth stage in the flooded paddy field.

the milking stage increased by $0.3 \mathrm{mgkg}^{-1}$ and $0.2 \mathrm{mgkg}^{-1}$, where the increment was less than that of the $0-10 \mathrm{~cm}$ soil layers. Additionally, at the same depth of submergence, the greater the leakage, the lower the RAP content, which may be related to the downward movement of some RAP after leaching.

\section{Changes to the Soil Redox Potential Eh Value in Paddy Soil}

The soil Eh values in the $15 \mathrm{~cm}$ soil layer of each growth stage are shown in Fig. 4. Before the water level was controlled, the Eh value of each treatment had little difference; during the flooded period, the Eh value of 

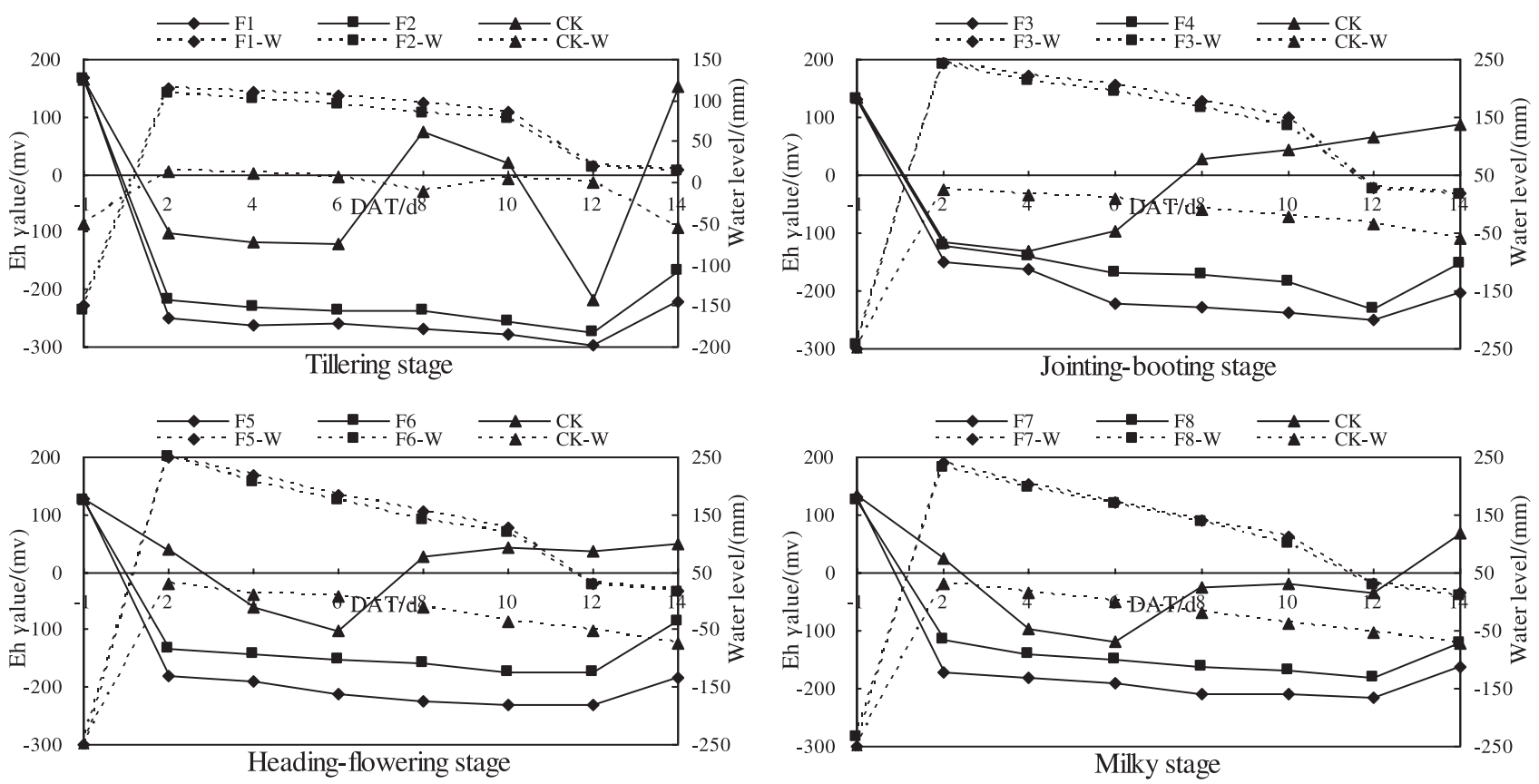

Fig. 4. Changes in Eh value in the $15 \mathrm{~cm}$ soil layer at each growth stage in the flooded paddy field (F1-W, F2-W, and CK-W represent the water levels of the treatments F1, F2, and CK).

the flooded treatment decreased rapidly and then further decreased after the controlled drainage was conducted, where the soil aeration also became worse. By contrast with the $\mathrm{CK}$, the Eh value was always higher and fluctuated from time to time, which was related to the soil moisture, namely that water flooding may reduce the soil Eh value. This is due to the soil pores being filled with water to greatly reduce the oxygen after the flooded depth in the paddy field; furthermore, through biological activity, more $\mathrm{CO}_{2}, \mathrm{H}_{2} \mathrm{~S}$, organic acids, and low iron and manganese were accumulated, the oxygen pressure of the air in soil was decreased, reducible substances were increased, and the Eh value was decreased. After the flood period ended, the Eh value of each treatment rose with varying degrees. Additionally, during the whole flood period, the mean value of Eh, for treatment with leakage intensity of $2 \mathrm{~mm} / \mathrm{d}$, was lower than that of the treatment with leakage intensity of $4 \mathrm{~mm} / \mathrm{d}$, which showed that the greater the leakage intensity, the better the soil aeration condition; this is just because when a certain leakage is maintained, the leaked water brings the dissolved oxygen and the efficient nutrients into it and removes some toxic substances from the soil, which improves soil redox. In fact, in order to eliminate the adverse factors and promote growth of the paddy rice, a very important measure is to drain water and dry the paddy field in sunshine. The leakage of the paddy field is one of the important characteristics of the paddy soil; generally, an appropriate leakage velocity is deemed to be beneficial to regulate the water, fertility, gas, and heat condition and the rhizospheric chemical environment of the root zone of the paddy rice, eliminate the reductive toxic substances (such as $\mathrm{H}_{2} \mathrm{~S}$ and organic acid), and promote the vigorous growth of the paddy rice. However, the large leakage in the paddy field is easy to cause the loss of moisture and nutrients, increase cultivation cost, and cause environmental pollution; therefore, it is favorable for the growth of the paddy rice to maintain appropriate leakage.

\section{Changes of Soil Temperature in Paddy Soil}

The ST values in the $5 \mathrm{~cm}$ and $20 \mathrm{~cm}$ soil layers at each growth stage are shown in Fig. 5. We can see that the irrigation method of the $5 \mathrm{~cm}$ soil layer was the shallow irrigation before controlled drainage, where the ST of each treatment had little difference. For treatment involving large differences, the human factors and the marginal effect should be considered. During the flooded period, as the flooded period continues, the ST under the flooded treatment tended to rise, and the daily mean ST was higher than that of the contrast treatment CK. After the controlled drainage period ended and was compared with the CK, $\mathrm{F} 1$ and $\mathrm{F} 2$ increases at the tillering stage were $1.7^{\circ} \mathrm{C}$ and $1.6^{\circ} \mathrm{C}$, respectively; $\mathrm{F} 3$ and $\mathrm{F} 4$ increase at the jointingbooting stage was $0.3^{\circ} \mathrm{C}$ and $0.2^{\circ} \mathrm{C}$, respectively; F5 and $\mathrm{F} 6$ increase at the heading-flowering stage was $1.33^{\circ} \mathrm{C}$ and $0.79^{\circ} \mathrm{C}$, respectively; and $\mathrm{F} 7$ and $\mathrm{F} 8$ increase at the milking stage was $0.95^{\circ} \mathrm{C}$ and $0.92^{\circ} \mathrm{C}$, respectively. Two days later after the controlled drainage period ended, the ST decreased slightly, except that of the milking stage, and the ST of the flooded treatment was still higher than that of CK. For the $20 \mathrm{~cm}$ soil layer, during the flooded period, the ST of flooded treatment was increased, except for that of the heading-flowering stage, and the ST was higher than that of the $\mathrm{CK}$; after the flooded period 

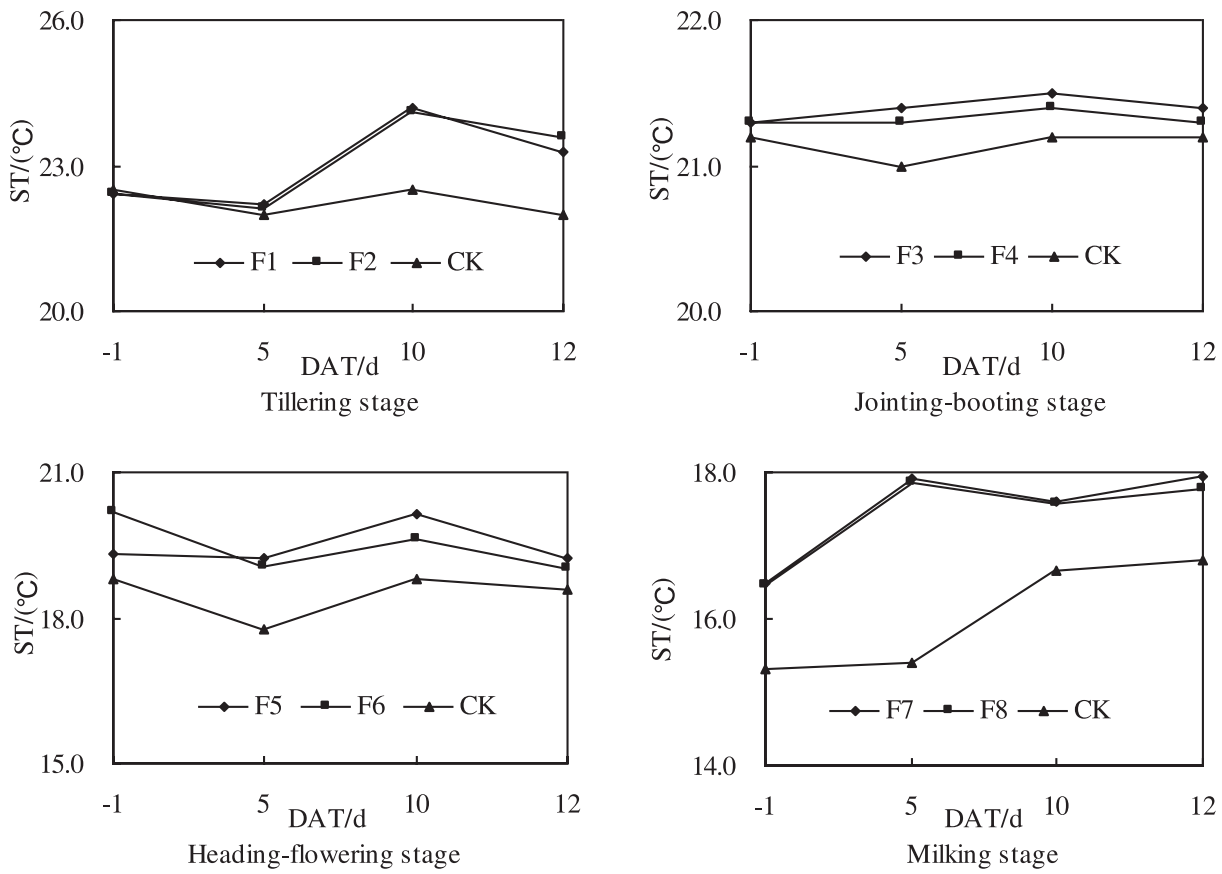

a) $5 \mathrm{~cm}$ layer
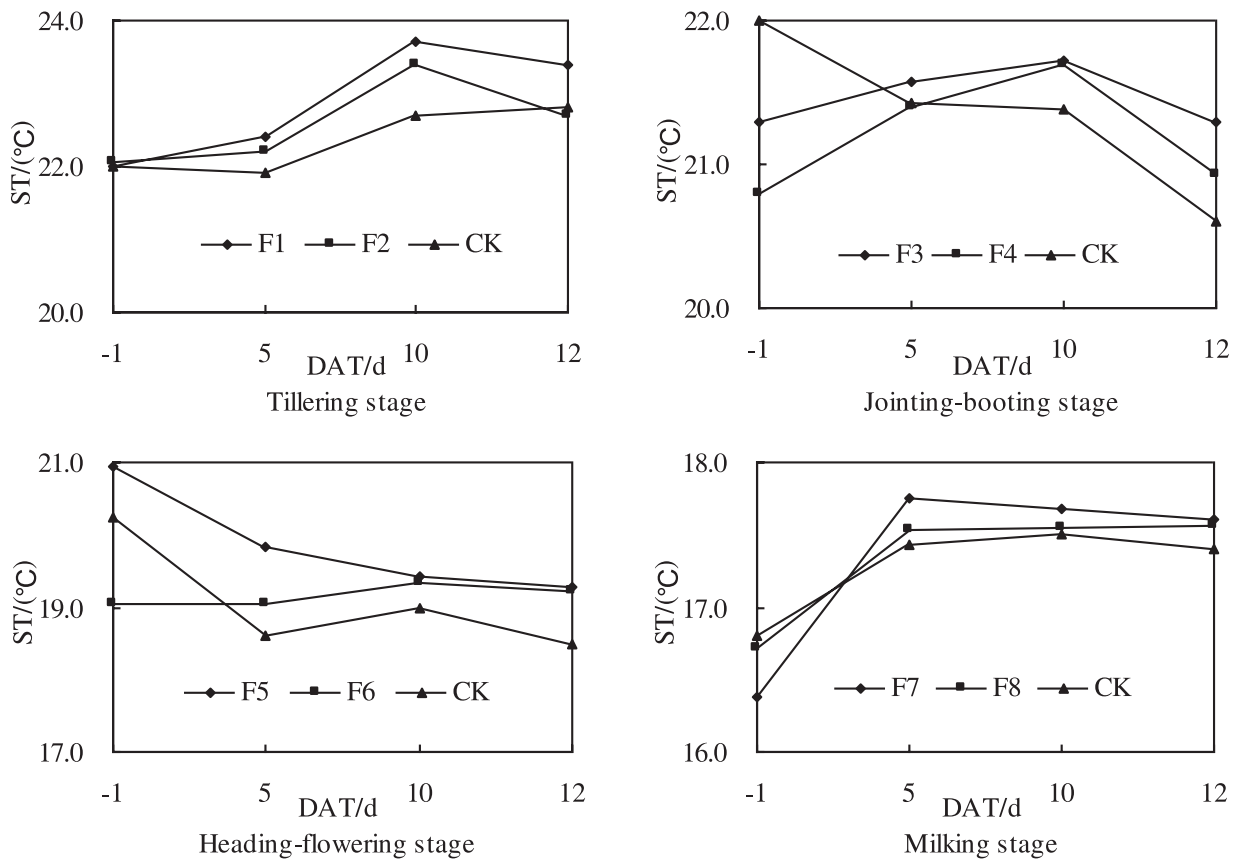

b) $20 \mathrm{~cm}$ layer

Fig. 5. Changes of ST value in the a) $5 \mathrm{~cm}$ and b) $20 \mathrm{~cm}$ soil layers at each growth stage in the flooded paddy field.

ended and compared with $\mathrm{CK}, \mathrm{F} 1$ and F2 increase at the tillering stage was $1.0^{\circ} \mathrm{C}$ and $0.72^{\circ} \mathrm{C}$, respectively; $\mathrm{F} 3$ and $\mathrm{F} 4$ increase at the jointing-booting stage was $0.34^{\circ} \mathrm{C}$ and $0.31^{\circ} \mathrm{C}$, respectively; F5 and $\mathrm{F} 6$ increase at the headingflowering stage was $0.41^{\circ} \mathrm{C}$ and $0.33^{\circ} \mathrm{C}$, respectively; and $\mathrm{F} 7$ and $\mathrm{F} 8$ increase at the milking stage was $0.10^{\circ} \mathrm{C}$ and $0.05^{\circ} \mathrm{C}$, respectively.

After the controlled drainage period ended, the ST of each treatment was decreased, and the ST of the flooded treatment was still higher than that of CK. Additionally, the ST with the leakage intensity of $2 \mathrm{~mm} / \mathrm{d}$ and $4 \mathrm{~mm} / \mathrm{d}$ had the same change trend, where the ST of $2 \mathrm{~mm} / \mathrm{d}$ leakage intensity was slightly higher than that of $4 \mathrm{~mm} / \mathrm{d}$ leakage intensity. The above showed that the water flooding made the ST increase. This is rightly due for the following reasons: the water of a certain depth maintained in the field under the flooded treatment dissipates its heat slowly (since the specific heat of water is higher) in the same solar radiation strength. During the flooded period, the ST value was affected by the air temperature, whichever it is the surface layer or the deeper layer; where the higher the air temperature is, the higher the ST value is and the larger 
Table 2. The influence analysis of different water controls and leakage intensities on the indicators of RAN, RAP, Eh, and ST.

\begin{tabular}{|c|c|c|c|c|c|c|c|c|}
\hline \multirow{2}{*}{$\begin{array}{l}\text { Growth } \\
\text { stage }\end{array}$} & \multirow[b]{2}{*}{ Treatment } & \multicolumn{2}{|c|}{$\operatorname{RAN}\left(\mathrm{mgkg}^{-1}\right)$} & \multicolumn{2}{|c|}{$\operatorname{RAP}\left(\mathrm{mgkg}^{-1}\right)$} & \multirow{2}{*}{$\begin{array}{c}\text { Eh }(\mathrm{mv}) \\
\begin{array}{c}15 \mathrm{~cm} \\
\text { layer }\end{array}\end{array}$} & \multicolumn{2}{|c|}{ ST $\left({ }^{\circ} \mathrm{C}\right)$} \\
\hline & & $\begin{array}{c}0-10 \mathrm{~cm} \\
\text { layer }\end{array}$ & $\begin{array}{c}10-20 \mathrm{~cm} \\
\text { layer }\end{array}$ & $\begin{array}{l}0-10 \mathrm{~cm} \\
\text { layer }\end{array}$ & $\begin{array}{c}10-20 \mathrm{~cm} \\
\text { layer }\end{array}$ & & $\begin{array}{l}5 \mathrm{~cm} \\
\text { layer }\end{array}$ & $\begin{array}{l}20 \mathrm{~cm} \\
\text { layer }\end{array}$ \\
\hline \multirow{3}{*}{ Tillering } & $\mathrm{F} 1$ & $11.72 \pm 1.04 \mathrm{~b}$ & $10.50 \pm 0.52 \mathrm{~b}$ & $26.30 \pm 0.60 a^{*}$ & $22.98 \pm 0.25 \mathrm{a}$ & $-208.41 \pm 54.22 b$ & $23.03 \pm 0.46 \mathrm{a} *$ & $22.88 \pm 0.40 \mathrm{a}$ \\
\hline & F2 & $12.68 \pm 0.69 b$ & $11.32 \pm 0.29 \mathrm{a}^{*}$ & $26.02 \pm 0.57 \mathrm{a}^{*}$ & $22.80 \pm 0.26 \mathrm{a}$ & $-181.95 \pm 50.88 b$ & $23.05 \pm 0.48 \mathrm{a}^{*}$ & $22.59 \pm 0.03 \mathrm{a}$ \\
\hline & $\mathrm{CK}$ & $15.56 \pm 0.29 \mathrm{a}^{*}$ & $12.00 \pm 0.63 \mathrm{a}^{*}$ & $24.94 \pm 0.27 \mathrm{~b}$ & $22.90 \pm 0.30 \mathrm{a}$ & $-42.64 \pm 66.73 a^{*}$ & $22.25 \pm 0.14 b$ & $22.35 \pm 0.05 \mathrm{a}$ \\
\hline \multirow{3}{*}{$\begin{array}{c}\text { Jointing- } \\
\text { booting }\end{array}$} & F3 & $12.08 \pm 1.18 \mathrm{~b}$ & $10.60 \pm 0.57 \mathrm{a}$ & $27.18 \pm 0.42 \mathrm{a}$ & $22.72 \pm 0.19 \mathrm{a}$ & $-165.70 \pm 44.07 b$ & $21.40 \pm 0.04 \mathrm{a}^{*}$ & $21.47 \pm 0.10 \mathrm{a}$ \\
\hline & F4 & $12.88 \pm 0.99 b$ & $11.02 \pm 0.40 \mathrm{a}$ & $26.86 \pm 0.38 \mathrm{a}$ & $22.46 \pm 0.14 \mathrm{a}$ & $-129.99 \pm 39.17 b$ & $21.33 \pm 0.03 \mathrm{a}^{*}$ & $21.20 \pm 0.21 \mathrm{a}$ \\
\hline & $\mathrm{CK}$ & $15.94 \pm 0.10 \mathrm{a}^{*}$ & $11.46 \pm 0.20 \mathrm{a}$ & $26.74 \pm 0.31 \mathrm{a}$ & $22.72 \pm 0.24 \mathrm{a}$ & $-17.88 \pm 33.55 \mathrm{a}^{*}$ & $21.15 \pm 0.05 b$ & $21.36 \pm 0.23 \mathrm{a}$ \\
\hline \multirow{3}{*}{$\begin{array}{l}\text { Heading- } \\
\text { flowering }\end{array}$} & F5 & $12.58 \pm 1.12 \mathrm{~b}$ & $9.94 \pm 0.51 \mathrm{a}$ & $27.48 \pm 0.32 \mathrm{a}$ & $23.30 \pm 0.28 \mathrm{a}$ & $-166.06 \pm 42.76 b$ & $19.48 \pm 0.23 \mathrm{a}^{*}$ & $19.87 \pm 0.38 \mathrm{a}$ \\
\hline & F6 & $13.38 \pm 0.85 b$ & $10.28 \pm 0.40 \mathrm{a}$ & $27.26 \pm 0.26 \mathrm{a}$ & $23.18 \pm 0.24 \mathrm{a}$ & $-112.21 \pm 35.35 b$ & $19.46 \pm 0.28 \mathrm{a}^{*}$ & $19.16 \pm 0.07 \mathrm{a}$ \\
\hline & $\mathrm{CK}$ & $15.72 \pm 0.12 \mathrm{a}^{*}$ & $10.96 \pm 0.20 \mathrm{a}$ & $27.20 \pm 0.21 \mathrm{a}$ & $23.34 \pm 0.28 \mathrm{a}$ & $10.79 \pm 25.76 \mathrm{a}^{*}$ & $18.50 \pm 0.25 b$ & $19.08 \pm 0.40 \mathrm{a}$ \\
\hline \multirow{3}{*}{ Milking } & F7 & $12.68 \pm 1.07 \mathrm{~b}$ & $8.86 \pm 0.56 \mathrm{~b}$ & $27.82 \pm 0.27 \mathrm{a}$ & $24.16 \pm 0.25 \mathrm{a}$ & $-151.33 \pm 40.78 b$ & $17.49 \pm 0.34 \mathrm{a}^{*}$ & $17.35 \pm 0.33 \mathrm{a}$ \\
\hline & F8 & $13.22 \pm 0.84 b$ & $9.68 \pm 0.27 \mathrm{a}^{*}$ & $27.60 \pm 0.19 \mathrm{a}$ & $24.04 \pm 0.21 \mathrm{a}$ & $-114.67 \pm 35.23 b$ & $17.41 \pm 0.33 \mathrm{a}^{*}$ & $17.34 \pm 0.21 \mathrm{a}$ \\
\hline & $\mathrm{CK}$ & $15.32 \pm 0.09 \mathrm{a}^{*}$ & $10.34 \pm 0.08 \mathrm{a}^{*}$ & $27.60 \pm 0.26 \mathrm{a}$ & $23.80 \pm 0.16 \mathrm{a}$ & $-7.83 \pm 29.42 \mathrm{a}^{*}$ & $16.04 \pm 0.40 \mathrm{~b}$ & $17.28 \pm 0.16 \mathrm{a}$ \\
\hline
\end{tabular}

$*$ = significant at the 0.05 level.

the temperature difference between the flooded treatment and CK; such a point can be seen from the changes in the ST on the 10th flooded day (daily maximum temperature $30^{\circ} \mathrm{C}$ ) and the second day after the flooded period (daily maximum temperature of $34^{\circ} \mathrm{C}$ ) at the tillering stage. In general, the soil temperature increased during the day but decreased at night by the influence of solar radiation. The temperature difference between the day and the night was very useful to improve the formation of paddy ecological environment and rice yield [23]. Flooding increased the ST, which may result in the decrement of accumulated temperature, which in turn will be adverse for rice growth.

\section{Influence Analysis of Variance for RAN, RAP, Eh, and ST}

From the changes of RAN, RAP, Eh, and ST, it was shown that different water level control will have a certain effect on the change of RAN, RAP, Eh, and ST in the rootzone soil of a paddy field. Significant results of the indicator of RAN, RAP, Eh, and ST under the conditions of different

Table 3. The index values of RAP, RAN, Eh, and ST at each growth stage in 2014 and 2015.

\begin{tabular}{|c|c|c|c|c|c|}
\hline Growth stage & Scheme & $\begin{array}{l}\text { RAP content } \\
\left(\mathrm{mgkg}^{-1}\right)\end{array}$ & $\begin{array}{l}\text { RAN content } \\
\left(\mathrm{mgkg}^{-1}\right)\end{array}$ & $\begin{array}{l}\text { Eh value } \\
\text { (mv) }\end{array}$ & $\begin{array}{c}\text { ST value } \\
\left({ }^{\circ} \mathrm{C}\right)\end{array}$ \\
\hline \multirow{3}{*}{ Tillering stage } & F1 & 22.9 & 10.5 & -208.4 & 22.88 \\
\hline & $\mathrm{F} 2$ & 22.8 & 11.3 & -182 & 22.59 \\
\hline & $\mathrm{CK}$ & 23.1 & 12 & -42.64 & 22.35 \\
\hline \multirow{3}{*}{ Jointing-booting stage } & F3 & 22.72 & 10.6 & -211.4 & 21.74 \\
\hline & $\mathrm{F} 4$ & 22.46 & 11 & -180 & 21.2 \\
\hline & CK & 22.9 & 11.5 & -50.4 & 21.43 \\
\hline \multirow{3}{*}{ Heading-flowering stage } & F5 & 23.32 & 9.94 & -225.4 & 19.87 \\
\hline & F6 & 23.18 & 10.28 & -210 & 19.16 \\
\hline & CK & 23.42 & 10.96 & -51 & 19.08 \\
\hline \multirow{3}{*}{ Milking stage } & F7 & 24.2 & 8.9 & -229 & 17.35 \\
\hline & F8 & 24 & 9.7 & -211.5 & 17.34 \\
\hline & CK & 23.9 & 10.3 & -52.2 & 17.28 \\
\hline
\end{tabular}


Table 4. Total variance explained of initial Eigenvalues and extraction sum of squared loadings in 2014 and 2015.

\begin{tabular}{|c|c|c|c|c|c|c|c|}
\hline \multirow{2}{*}{$\begin{array}{l}\text { Growth } \\
\text { stage }\end{array}$} & \multirow{2}{*}{ Component } & \multicolumn{3}{|c|}{ Initial Eigenvalues } & \multicolumn{3}{|c|}{ Extraction Sums of Squared Loadings } \\
\hline & & Total & $\%$ of Variance & Cumulative $\%$ & Total & $\%$ of Variance & Cumulative $\%$ \\
\hline \multirow{4}{*}{$\begin{array}{l}\text { Tillering } \\
\text { Stage }\end{array}$} & 1 & 3.489 & 87.217 & 87.217 & 3.489 & 87.217 & 87.217 \\
\hline & 2 & 0.511 & 12.783 & 100.000 & & & \\
\hline & 3 & 0.000 & 0.000 & 100.000 & & & \\
\hline & 4 & 0.000 & 0.000 & 100.000 & & & \\
\hline \multirow{4}{*}{$\begin{array}{c}\text { Jointing- } \\
\text { booting } \\
\text { stage }\end{array}$} & 1 & 2.470 & 61.761 & 61.761 & 2.470 & 61.761 & 61.761 \\
\hline & 2 & 1.530 & 38.239 & 100.000 & 1.530 & 38.239 & 100.000 \\
\hline & 3 & 0.000 & 0.000 & 100.000 & & & \\
\hline & 4 & 0.000 & 0.000 & 100.000 & & & \\
\hline \multirow{4}{*}{$\begin{array}{c}\text { Heading- } \\
\text { flowering } \\
\text { stage }\end{array}$} & 1 & 2.964 & 74.105 & 74.105 & 2.964 & 74.105 & 74.105 \\
\hline & 2 & 1.036 & 25.895 & 100.000 & 1.036 & 25.895 & 100.000 \\
\hline & 3 & 0.000 & 0.000 & 100.000 & & & \\
\hline & 4 & 0.000 & 0.000 & 100.000 & & & \\
\hline \multirow{4}{*}{$\begin{array}{l}\text { Milking } \\
\text { stage }\end{array}$} & 1 & 3.701 & 92.519 & 92.519 & 3.701 & 92.519 & 92.519 \\
\hline & 2 & 0.299 & 7.481 & 100.000 & & & \\
\hline & 3 & 0.000 & 0.000 & 100.000 & & & \\
\hline & 4 & 0.000 & 0.000 & 100.000 & & & \\
\hline
\end{tabular}

water level controls were done using SPSS 19.0 software. The results are listed in Table 2, which shows that for the 0-10 cm layer different water level controls between CK (shallow and wetting irrigation) and F1 and F2 (controlled drainage) had a significant effect on the changes of RAN content, and different leakage intensity had no significant effect on the change of RAN content. For the 10-20 cm layer different water level controls and leakage intensity had no effect on RAN content except at the tillering stage. For the RAP content change, different water level controls and leakage had no significance in the $0-10 \mathrm{~cm}$ or the $10-20 \mathrm{~cm}$ soil layers except at the tillering stage in the 0-10 cm layer. Moreover, different water level controls were significant for the Eh value changes, but different leakage had no significance on the Eh value changes in the $15 \mathrm{~cm}$ soil layer. Additionally, for the $5 \mathrm{~cm}$ soil layer, different water level controls had significant effects on the ST value changes, but different leakage intensities played no significant roles in the ST value changes for the $15 \mathrm{~cm}$ soil layer, and different water level controls and leakage intensity had no significant effect on the ST value change. The different effect on RAN and RAP content resulted from different chemical characteristics of RAN and RAP on the one hand, and the different absorption characteristics of crops on the other. RAN was closely related to crop growth, including ammonium nitrogen, nitrate nitrogen, total amino acid, protein nitrogen, and amide and easy hydrolysis. RAN content reflected the soil nitrogen supply in the near future, and had a great significance in fertilization recommendation. Most phosphorus was polymer state and validity was not high [24-25].

\section{Impact of the Water-fFlooding on Soil Micro-Environment}

This paper discussed the change law of soil fertilizer, soil aeration condition, and soil temperature under the controlled-drainage condition of the flooded paddy field, where the results showed that controlled drainage had a significant impact on the soil micro-environment. In order to analyze further the impact and the scope of the controlled drainage on and for the soil environment, the experimental treatments were chosen as the independent schemes, the indexes of RAP, RAN, Eh, and ST as the variables, and then the principal component and the principal component scores of every scheme were analyzed to evaluate the quality of every scheme. There were eight controlled drainage schemes; since there were larger differences in the soil environment conditions at each growth stage, it was analyzed and evaluated by stages; whereas for the index values, the RAP, RAN, Eh, and ST values before and after the controlled drainage were subject to their respective mean values. Meanwhile, the RAP and RAN in the 10-20 cm soil layer were the representative, the Eh values in the $15 \mathrm{~cm}$ soil layer, and the ST values in the $20 \mathrm{~cm}$ soil layer were the respective representatives for making the comprehensive investigation. The values of each index at different growth stages are shown in Table 3.

The descriptive statistics are shown in Table 4. Among 


$$
\mathrm{M}_{\mathrm{t}}=\left|\begin{array}{c}
-0.817 \\
-0.298 \\
1.115
\end{array}\right| \mathrm{M}_{\mathrm{j}}=\left|\begin{array}{cc}
-0.782 & 0.85 \\
-0.345 & -1.102 \\
1.1271 & 0.2522
\end{array}\right| \mathrm{M}_{\mathrm{h}}=\left|\begin{array}{cc}
-1.146 & 0.839 \\
0.453 & -1.062 \\
0.693 & 0.237
\end{array}\right| \mathrm{M}_{\mathrm{m}}=\left|\begin{array}{c}
-0.91 \\
-0.16 \\
1.07
\end{array}\right|
$$

Fig. 6. The component matrix of each growth. $\mathrm{Mt}, \mathrm{Mj}, \mathrm{Mh}$, and $\mathrm{Mm}$ represented the component matrix of tillering, jointing-booting, heading-flowering, and milking stages, respectively.

all explained variances, at tillering stage the contribution rate of the first principal component to be extracted was $87.22 \%$, which was higher than $80 \%$ and represented a majority of the information. At the jointing-booting stage, the contribution rate extracted for the first principal component was $61.76 \%$, where the total contribution rate of the first two principal components was $100 \%$. The first two principal components have enough information and can be identified as the principal components. At the heading-flowering stage, the contribution rate extracted for the first principal component was $74.11 \%$, where the total contribution rate of the first two principal components was $100 \%$, and the first two such principal components have enough information and could be identified as the principal components. At milking stage, the contribution rate extracted for the first principal component was $92.519 \%$, and such a first principal component had enough information and could be identified as the principal component.

The component matrix of each growth stage is shown in Fig. 6, and it can be seen that at tillering stage CK was maximum, with F2 and F1 following, which meant water flooding at the tillering stage would definitely have an adverse impact on the soil microenvironment, including the negative impact on RAP, RAN, Eh, and ST. Upon the comparison, it was found that $\mathrm{F} 2$ had a higher score, which meant that the larger leakage retention can effectively reduce the negative impact of the water-logging on the soil environment of the paddy field. At the jointing-booting stage for the first principal component, the score of $\mathrm{CK}$ was highest, with F4 and F3 following; for the second principal component the score of F3 was highest, with CK and F4 following. Based on the information represented by the two principal components, this indicated that the waterlogging in the paddy field at the jointing-booting stage may cause negative impact on the RAN and Eh of the paddy soil, where the larger leakage can cause negative impact on the ST of the paddy field. At the heading-flowering stage and for the first principal component, the score of $\mathrm{CK}$ was highest, with that of F6 and F5 following. For the second principal component, the score of F5 was highest, with that of CK and F6 following. This indicated that the water-logging in the paddy field at the heading-flowering stage would cause a negative impact on the RAN and Eh of the paddy soil. And for the second principal, the score of the F5 was higher than that of F6, which indicated that the larger leakage was not beneficial to the RAP and ST. At the milking stage, the score of CK was highest, with that of F8 and F7 following, which showed that the waterlogging in the paddy field at the milking stage may affect the RAP, RAN, Eh, and ST of the paddy soil; meanwhile, the increased leakage could relieve the adverse influence caused by water-logging.

\section{Conclusions}

Under flood conditions, the RAN content in the 0-10 $\mathrm{cm}$ and $10-20 \mathrm{~cm}$ soil layers showed a decreasing trend. Compared with that of the first flooded day, the RAP in the $0-10 \mathrm{~cm}$ and $10-20 \mathrm{~cm}$ soil layers on the $10^{\text {th }}$ flooded day was decreased by $17.9-30.7 \%$ and $10.3-24 \%$, respectively; additionally, the greater the leakage, the higher the RAN in soil, which indicated that the greater leakage can effectively reduce the loss of RAN. The RAP in soil decreased as soil depth increased, where the RAP of every soil layer after the controlled-drainage increased at different levels, and the RAN in soil after the flooded treatment was higher than of the CK.

Secondly, compared with CK on the $10^{\text {th }}$ flooded day, the RAP increased by $0.4-2.0 \mathrm{mgkg}^{-1}$ for the $0-10 \mathrm{~cm}$ soil layer and $0.1-0.5 \mathrm{mgkg}^{-1}$ for the $10-20 \mathrm{~cm}$ soil layer; under the same water-logging depth, the greater the leakage, the lower the RAP. The water-logging may obviously reduce the Eh value of soil; the larger the leakage, the higher the Eh value and the better the soil aeration conditions.

Thirdly, the water-logging could make the ST rise. On the 10th flooded day and compared with CK, the ST increase in the $5 \mathrm{~cm}$ and the $20 \mathrm{~cm}$ soil layers was $0.2-1.7^{\circ} \mathrm{C}$ and $0.05-1.0^{\circ} \mathrm{C}$, respectively. The treatment on the leakage of $2 \mathrm{~mm} / \mathrm{d}$ and $4 \mathrm{~mm} / \mathrm{d}$ had the same change trend. The ST with the smaller leakage was slightly higher than that of the larger leakage. Additionally, during the water-drainage period, the soil was affected by the air temperature, whichever it was the surface layer or the deeper layer. The higher the air temperature, the higher the ST and the larger the difference in the temperature of the contrast treatment.

In addition, influence analysis results showed that different water level controls between CK (shallow and wetting irrigation) and F1 and F2 (controlled drainage) had a significant effect on the changes of RAN content in the $0-10 \mathrm{~cm}$ layer, Eh value in $15 \mathrm{~cm}$ layer and $\mathrm{ST}$ value in the $5 \mathrm{~cm}$ layer, but different leakage intensity had no significant effect on the change of RAN, RAP, Eh, and ST. Lastly, by analyzing the principal component score of every treatment in the flooded paddy field using the principal component analysis approach, the water-logging at the tillering and the milking stage had a negative impact on the RAP, RAN, Eh, and ST of the soil in the paddy 
field, where the greater leakage could relieve the adverse impact caused by the water-logging, the water-logging at the jointing-booting, and the heading-flowering stage had the negative impact on the RAN and Eh of soil of the paddy field. The leakage at both such growth stages was very crucial, where the large leakage was unfavorable to the RAP and ST.

\section{Acknowlegements}

Our research was financially supported by the National $\mathrm{NaOur}$ research was financially supported by the National Natural Science Fund (No. 51409124 and 51679108), the Natural Science Foundation of Jiangsu Province (No. BK20140564), the postdoctoral foundation of Jiangsu Province (No. 1401142C), and a project funded by Priority Academic Program Development of Jiangsu Higher Education Institutions.(PDPA).

\section{References}

1. TABBAL D.F., BOUMAN B.A.M., BHUIYAN S.I., SIBAYAN E.B., SATTAR M.A.. On-farm strategies for reducing water input in irrigated rice; case studies in the Philippines. Agricultural Water Management. 56, 93, 2002.

2. BELDER P., BOUMAN B.A.M., CABANGON R., GUOAN L., QUILANG E.J.P., LI Y.H., SPIERTZ J.H.J., TUONG T.P. Effect of water-saving irrigation on rice yield and water use in typical lowland conditions in Asia. Agricultural Water Management. 65, 193, 2004.

3. CHEN A., LEI B., HU W., LU Y., MAO Y., DUAN Z. Characteristics of ammonia volatilization on rice grown under different nitrogen application rates and its quantitative predictions in Erhai Lake Watershed, China. Nutrient Cycling in Agroecosystems. 101 (1), 139, 2015.

4. NORSE D. Non-Point Pollution from crop production: global,regional and national issues. Pedosphere. 15 (4), 499, 2005.

5. JU X.T., XING G.X., CHEN X.P., ZHANG S.L., ZHANG L.J., LIU X.J., CUI Z.L., YIN B., CHRISTIE P., ZHU Z.L., ZHANG F.S. Reducing environmental risk by improving $\mathrm{N}$ management in intensive chinese agricultural systems. Proceedings of the National Academy of Sciences of the United States of America. 106, 3041, 2009.

6. LI H., LIANG X.Q., CHEN Y.X., TIAN G.M., ZHANG Z.J. Ammonia volatilization from urea in rice fields with zero-drainage water management. Agricultural Water Management. 95, 887, 2008

7. CHIRINDA N., CATER M.S., ALBERTB K.R., AMBUS P., OLESEN J.E., PORTER J.R., PETERSEN S.O. Emissions of nitrous oxide from arable organic and conventional cropping systems on two soil types. Agriculture Ecosystems \& Environment. 136, 199, 2010.

8. PIEROBON E., CASTALDELLI G., MANTOVANI S., VINCENZI F., FANO E.A. Nitrogen removal in vegetated and unvegetated drainage ditches impacted by diffuse and point sources of pollution. CLEAN-Soil, Air, Water. 41 (1), 24, 2013.

9. GILLIAM J.W., SKAGGS R.W., WEED S.B. Drainage control to diminish nitrate loss from agricultural fields. Journal of Environmental Quality. 8, 137, 1994.
10. SKAGGS R.W., GILLIAM J.W., EVANS R.O. Controlled Versus Conventional Drainage Effects on Water Quality[J]. Journal of Irrigation \& Drainage Engineering. 121 (4), 271, 2014.

11. PENG S.Z., YANG S.H., XU J.Z., LUO Y.F., HOU H.J. Nitrogen and phosphorus leaching loss from paddy field with different water and nitrogen management. Paddy and water environment. 9, 333, 2011.

12. DELIN S., STENBERG M. Effect of nitrogen fertilization on nitrate leaching in relation to grain yield response on loamy sand in Sweden. European Journal of Agronomy. 52 (1), 291, 2014.

13. LI Y., LIU H., HUANG G., ZHANG R., YANG H. Nitrate nitrogen accumulation and leaching pattern at a winter wheat: summer maize cropping field in the North China Plain. Environmental Earth Sciences. 75 (2), 1, 2016.

14. YIN G.X., ZHANG Z.Y., GUO X.P., SHAO G.C. Experimental study on effect of controlled drainage from ground surface on concentration and discharge of nitrogen. Journal of Hohai University (Natural Sciences). 34, 21, 2006.

15. YANG L., HUANG J.S., ZHAO L., HUANG Z.Q. Experimental study on the distribution of soil nitrate and ammonium nitrogen under controlled drainage. Wuhan University Journal of Natural Sciences. 14, 532, 2009.

16. EHMKE T. Improving water and nutrient use efficiency with drainage water management. Crops and Soils. 46 (4), 6, 2013.

17. ASCHONITIS V.G., MASTROCICCO M., COLOMBANI N., SALEMI E., KAZAKIS N., VOUDOURIS K. Assessment of the intrinsic vulnerability of agricultural land to water and nitrogen losses via deterministic approach and regression analysis. Water, Air, \& Soil Pollution. 223 (4), 1605,2011

18. PENG S.Z., ZHANG Z.L., LUO Y.F., JIAO X., SUN $\mathrm{Y}$. Variation of nitrogen concentration in drainage water from paddy field under controlled irrigation and drainage. Transactions of the Chinese Society of Agricultural Engineering. 25, 21, 2009.

19. XIAO M.H., YU S.E., ZHANG Y.L. Changes of nitrogen concentration for surface and groundwater in flooding paddy field under controlled drainage. Transactions of the Chinese Society of Agricultural Engineering. 27, 180, 2011.

20. HART M.R., QUIN B.F., NGUYEN M.L. Phosphorus runoff from agricultural land and direct fertilizer effects: a review. Journal of Environmental Quality. 33, 1954, 2004.

21. YIN C.M., XIE X.L. Effects of irrigation methods on soil environment and rice yield in paddy ecosystems. Transactions of the Chinese Society of Agricultural Engineering. 26, 26, 2010.

22. LU M., LIU M., MAO G.F., HUANG M.W., QU P. Study on nitrogen leaching of paddy soil in the field experiments. Journal of East China Normal University (Natural Science). 4, 71, 2006.

23. LI D.X., PENG S.Z., XU J.Z., DING J.L., HE Y., YU J.Y. Effect of water-saving irrigation on eco-environment of paddy field. Journal of Hohai University (Natural Sciences). 33, 629, 2005

24. ZHANG Y.M., CHUN-SHENG H.U., ZHANG J.B., CHEN D.L., LI X.X.. Nitrate leaching in an irrigated wheat-maize rotation field in the North China Plain. Pedosphere. 15, 196, 2005.

25. ZHU Z.L., CHEN D.L. Nitrogen fertilizer use in ChinaContributions to food production, impacts on the environment and best management strategies. Nutrient Cycling in Agroecosystems Nutr Cycl Agroecos. 63, 117, 2002. 